\title{
Durability of recycled aggregate concrete designed with the Equivalent Mortar Volume (EMV) method: Validation under the Spanish context and its adaptation to Bolomey methodology
}

\author{
C. Jiménez ${ }^{\mathrm{a}} \bowtie$, M. Barra ${ }^{\mathrm{a}}, \mathrm{S}$. Valls $^{\mathrm{a}}$, D. Aponte ${ }^{\mathrm{a}}$, E. Vázquez ${ }^{\mathrm{a}}$ \\ a. Universidad Politécnica de Cataluña (Barcelona, España) \\ \cristian.jimenez@estudiant.upc.edu
}

Received 8 February 2013

Accepted 10 July 2013

Available on line 2 October 2013

\begin{abstract}
Some durability properties are analyzed in concretes made with a novel method for recycled aggregates concrete (RAC) proportioning, in order to validate it under the Spanish context. Two types of concrete mixes were elaborated; one following the guidelines of the named method, and other based on an adaptation of the method to Bolomey methodology. Two types of recycled concrete aggregates (RCA) were used. RCA replacement for natural aggregates (NA) ranged from $20 \%$ to $100 \%$. The $20 \%$ was chosen in order to comply with Spanish recommendations. Water penetration under pressure, water absorption and chlorides attack were the studied properties. It is verified that the new method and the developed adaptation results in concrete mixes of better or similar properties to those of the natural aggregates concrete (NAC) and the conventional RAC, saving important amounts of cement.
\end{abstract}

KEYWORDS: Portland Cement; Durability; Sustainability; Recycled Aggregates; Recycled Concrete

Citation / Citar como: Jiménez, C.; Barra, M.; Valls, S.; Aponte, D.; Vázquez, E. (2014). Durability of recycled aggregate concrete designed with the Equivalent Mortar Volume (EMV) method: Validation under the Spanish context and its adaptation to Bolomey methodology. Mater. Construcc. 64 [313], e006 http://dx.doi.org/10.3989/mc.2014.00913

RESUMEN: Durabilidad de hormigones con áridos reciclados diseñados con el método de Volumen de Mortero Equivalente (EMV): Validación bajo el contexto Español y adaptación a la metodología de Bolomey. Algunas propiedades de durabilidad son analizadas en hormigones elaborados con el nuevo método para la dosificación de hormigones con árido reciclado (HAR) para validarlo bajo el contexto español. Se elaboraron dos tipos de hormigones; uno siguiendo las directrices del nuevo método y otro basado en una adaptación del anterior a la metodología Bolomey. Se utilizaron dos tipos de árido reciclado (ARH). Los reemplazos de áridos variaron entre $20 \%$ y $100 \%$. El 20\% ha sido elegido para cumplir con recomendaciones españolas sobre HAR. Las propiedades estudiadas fueron: penetración de agua bajo presión, absorción de agua y susceptibilidad al ataque de cloruros. Se verifica que el nuevo método y la adaptación desarrollada resultan en hormigones con mejores o similares características que las de un hormigón con áridos naturales (HAN) y las de HAR convencional, ahorrando, además, importantes cantidades de cemento.

PALABRAS CLAVE: Cemento Portland; Durabilidad; Sostenibilidad; Áridos Reciclados; Hormigón Reciclado

Copyright: (C) 2014 CSIC. This is an open-access article distributed under the terms of the Creative Commons Attribution-Non Commercial (by-nc) Spain 3.0 License.

\section{INTRODUCTION}

There have been several improvements during these last years towards a sustainable construction. Specifically in the construction field, there is a generalized new way of thinking that strives on creating or upgrading processes, inventing new materials, enhancing their properties by making them more environmentally friendly, and so on. Among the most important issues in this subject there is the 
recycling of construction and demolition materials which, in Europe for example, has had an important impact, up to the point of creating regulations and special commissions in order to deal with this.

In the case of concrete, which is the most important material in construction $(1,2)$, some problem arises due to its components and its reusing or recycling. Although concrete is a green material (1), its production volumes represent a big problem, because of its disposal, when is treated as a waste, which is a main concern in urbanized countries where there is no more space for such purposes, and also because of the requirements on NA that it represents (3). Apart from this, the use of cement, as one of the most important constituents of the concrete, causes more problems due to its production procedure. According to the U.S. Environmental Protection Agency (EPA) (4), the amount of $\mathrm{CO}_{2}$ emissions for cement production, among other industrial processes, reaches the second place, after Steel and Metallurgical Coke production (41 Tg), with an amount of $29 \mathrm{Tg}$, exceeding by far the 11.8 Tg of the third activity (Ammonia Production \& Urea Consumption). Maier and Durham (5) stated that Portland cement is the largest contributor to greenhouse gases of all the raw materials used in concrete.

Concrete can be recycled in order to create new aggregates, and these aggregates can be used as a part of a new concrete mix commonly named recycled aggregates concrete (RAC). This goes towards the idea of sustainability, but it has an inconvenient which is that, today's beliefs indicate that in order to obtain similar characteristics of those of a natural aggregates concrete (NAC), the concrete mix will need higher amounts of cement, so while we are improving one issue, we need to worsen another on the other side.

In this matter, a new proportioning method for RAC has been created and tested. The method, named Equivalent Mortar Volume (EMV) by its authors (2), uses less new mortar in the mix based on the idea that the recycled aggregate is a two phase material, comprising old mortar and natural aggregate so, by resting the old mortar to the new needed one, same amount of total mortar as the one in a NAC can be attained. This will improve the properties of the RAC designed with the new method when compared to a normal RAC, which has worst properties due to an excess of mortar.

The mortar content reduction will imply a reduction in the cement content as well, which will turn the already green RAC into an even greener one. In addition to this, there is an economical implication due to the use of less amount of cement that, as it is the most expensive component of a concrete mix, will reduce the cost of it.

As durability is mainly affected by the surrounding environment, is logical to think that by taking a close attention to its superficial layer will end up in a properly durable concrete. In order to do this, several recommendations arise, such as a properly curing of the material, the use of additives in the mix proportioning, the use of products which intend to fill the surface pores of the concrete, or by avoiding the concrete exposition to harsh environments. Although this, many of the possibilities are not feasible sometimes due to the specifications of a project, economical issues, or the structure placement, among others.

One of the intentions of this investigation was to design a RAC which could reach good mechanical and durability properties in order to make it able for use in real practice.

\section{MATERIALS AND METHODS}

\subsection{Materials}

Concrete mixes components were a CEM I 42.5 $\mathrm{R}$ cement from CEMEX Co., two calcareous sands (I and II) and one calcareous coarse aggregate, and two RCA. The aggregates grading curves were presented in a previous investigation (6). RCA type A, was obtained by crushing old concrete specimens and its composition consisted of $89 \%$ of NA with attached mortar and $11 \%$ of clean NA. RCA type B was acquired from a Catalonian recycling company

TABLE 1. Physical characterization of aggregates

\begin{tabular}{lcccccc}
\hline $\begin{array}{l}\text { Property } \\
\text { Aggregate }\end{array}$ & Absorption (\%) & $\begin{array}{c}\text { OD specific gravity } \\
\left(\mathbf{k g} / \mathbf{m}^{3}\right)\end{array}$ & $\begin{array}{c}\text { SSD Density } \\
\left(\mathbf{k g} / \mathbf{m}^{3}\right)\end{array}$ & $\begin{array}{c}\text { Apparent Density } \\
\left(\mathbf{k g} / \mathbf{m}^{3}\right)\end{array}$ & $\begin{array}{c}\text { DR density } \\
\left(\mathbf{k g} / \mathbf{m}^{3}\right)\end{array}$ & $\begin{array}{c}\text { Mortar content } \\
(\%)\end{array}$ \\
\hline RCA & & & & & & \\
A & 6.0 & 2307 & 2446 & 2678 & 1311 & 39 \\
B & 4.7 & 2327 & 2440 & 2612 & 1329 & 32 \\
Natural aggregates & & & & & & \\
NA & 0.6 & 2671 & 2686 & 2713 & 1510 & - \\
Sand I & 0.7 & 2650 & 2670 & 2700 & - & - \\
Sand II & 1.6 & 2625 & 2665 & 2736 & - & - \\
\hline
\end{tabular}


Durability of recycled aggregate concrete designed with the Equivalent Mortar Volume (EMV) method $\bullet 3$

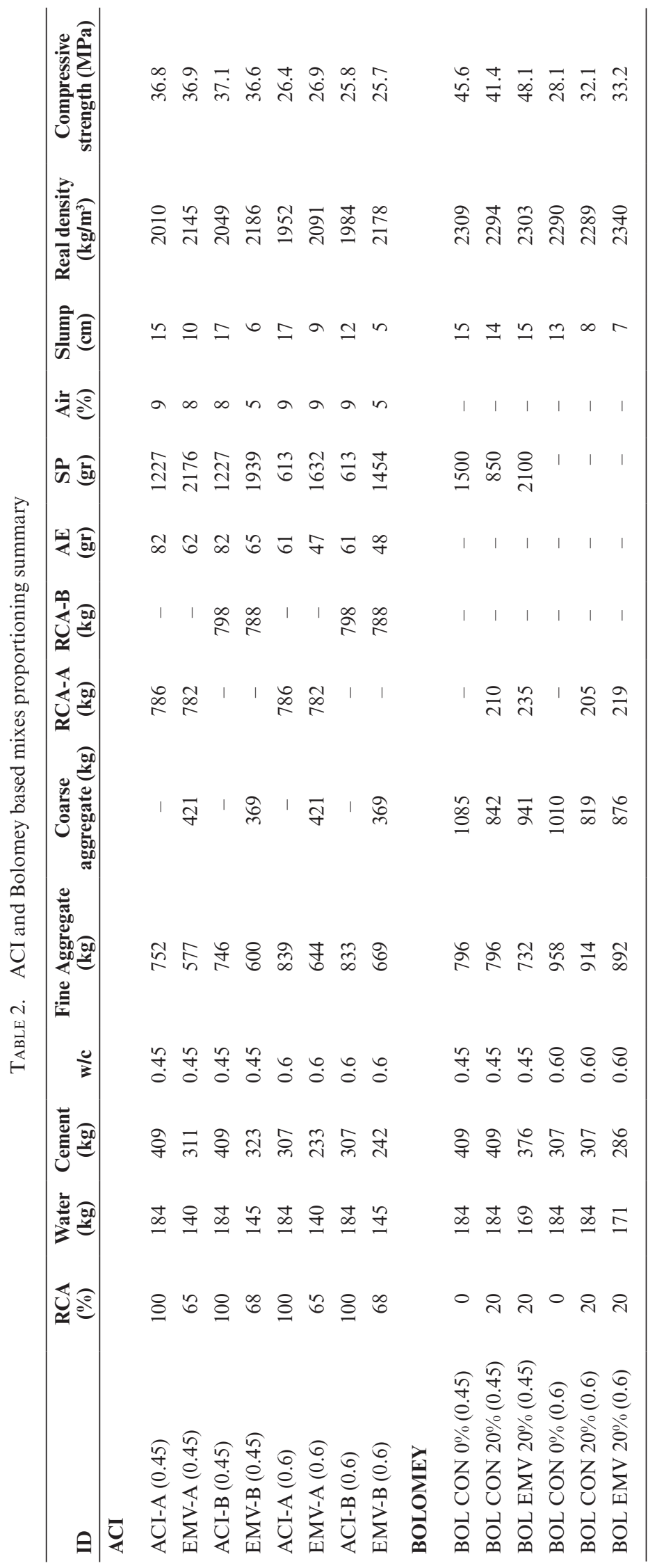


and consisted of $13 \%$ of bituminous material (which does not meets the requirements of the EHE-08 (7), $1 \%$ of ceramic impurities, $56 \%$ of NA with attached mortar and 30\% of clean NA. Glenium Sky 604 superplastizicer (SP) and Micro Air 100 air entrainer (AE), both from BASF Co., were the chosen additives. The aggregates characterization results are shown in Table 1.

The mortar content determination was done following the thermal attack methodology proposed by Barra (8).

\section{2. Mix designs}

The designed concretes were confectioned with different effective $\mathrm{w} / \mathrm{c}$ ratios, using additives in some cases, and different amounts and types of RCA, in order to evaluate their implication on the concretes properties. In the first part, ACI mix design was used to design concrete mixes with $100 \%$ NA replacement by RCA (ACI-A and ACI-B), and some other mixes were produced by using the novel method (2) (EMV-A and EMV-B). The letter A or B after ACI and EMV names represents the RCA type used. In the second part, a conventional mix comprising only NA and using Bolomey design (BOLCON 0\%), a conventional mix with a $20 \%$ NA replacement by RCA and using Bolomey methodology (BOLCON $20 \%$, and one mix designed with an adaptation of the novel method to Bolomey methodology (6) with a $20 \%$ NA replacement by RCA (BOLEMV 20\%) were prepared. Sand type I was used in ACI mixes while sand II was used in Bolomey ones. These are similar sands with only slight differences in their grading. Table 2 shows the mix proportions summary.

\subsection{Fresh and hardened concrete properties}

Along the whole investigation, several characteristics of the concrete were studied, starting from the fresh concrete properties such as slump (9), air content and fresh densities (10); followed by hardened concrete properties such as hardened densities (11), compressive strength (12) and static modulus of elasticity (13); and finally some durability properties. On this part of the investigation only the durability properties of the concrete will be addressed because all the other properties have been already published (6), and they will be mentioned purely for information purposes.

The durability properties studied on this part are capillary water absorption in hardened concrete (14), water penetration depth under pressure (15), chloride penetration in hardened concrete evaluated by $\mathrm{AgNO}_{3}$ solution (16) and penetration parameters for estimating the resistance against chloride penetration in hardened concrete (17).

\section{RESULTS AND DISCUSSION}

\subsection{Capillary water absorption}

The water absorption test was executed over cut sawed cylindrical specimens of $10 \mathrm{~cm}$ diameter. These were weighted, taken into a plastic container and immersed in water until $5 \mathrm{~mm}$ height were reached on the vertical surface of the specimen. Immediately after the immersion, the specimens were weighted again at different time lapses until constant mass was achieved. The results were obtained from the average of three test specimens for each mix.

In order to achieve a one dimensional pathway of the water through the samples and also to avoid water loss through their lateral surfaces, the specimens were coated with an impermeable paint on their vertical side.

It is worth noting that before starting the water absorption test, the specimens were conditioned according to UNE-83966:2008 (18). The conditioning aim is to achieve a certain relative humidity within the specimen in order to have comparable results when performing the water absorption test. In the case of this procedure, the specimens reach an internal relative humidity ranging from $65 \%$ to $75 \%$. The internal relative humidity of the specimens could change the results of the test as it is been studied by Castro et al. (19). They have found that specimens conditioned at $50 \%$ relative humidity have a 6 times greater total absorption than a specimen conditioned at $80 \%$ relative humidity, which clearly show us the importance of this procedure.

With the obtained data and using the graphs plotted with the water absorption vs. the square root of time, the absorption coefficients were calculated as the slope of the line which is formed between the 0.0 coordinate, representing zero absorption at a zero square root of time, and a point where the absorption clearly declines.

As it can be noticed in Table 3, in the case of the $0.45 \mathrm{w} / \mathrm{c}$ ratio, the capillary absorption coefficient of ACI mixes are around 1.7 times higher than the EMV ones. For $0.6 \mathrm{w} / \mathrm{c}$ ratio mixes, the absorption coefficient of ACI-A is around 3.6 times higher than the EMV-A ones, and ACI-B is about 4.2 times higher than the EMV-B. These results are attributed to the fact that EMV mixes have less amount of total mortar than ACI ones. Also, ACI mixes with a 0.6 w/c ratio present much higher values, which, in part, may be due to a combining effect of the reduction of SP and the high w/c ratio on these specific cases. A simple ANOVA test was carried out between different proportioning methodology and same RCA type and, in both cases, significant differences were encountered. The difference between both 0.45 and $0.6 \mathrm{w} / \mathrm{c}$ ratios may be due to the porous structure 
TABLE 3. Absorption coefficients of the ACI based mixes

\begin{tabular}{lccccc}
\hline & \multicolumn{2}{c}{$\mathbf{0 . 4 5} \mathbf{w} / \mathbf{c}$} & & \multicolumn{2}{c}{$\mathbf{0 . 6} \mathbf{w} / \mathbf{c}$} \\
\cline { 2 - 3 } \cline { 5 - 6 } & $\mathbf{k}$ & $\sigma$ & & $\mathbf{k}$ & $\sigma$ \\
\hline ACI-A & 0.0054 & 0.0001 & & 0.0204 & 0.0014 \\
ACI-B & 0.0040 & 0.0002 & & 0.0177 & 0.0006 \\
EMV-A & 0.0033 & 0.0000 & & 0.0057 & 0.0003 \\
EMV-B & 0.0024 & 0.0002 & & 0.0042 & 0.0002 \\
\hline
\end{tabular}

of these mixes, where the used increment of the w/c ratio seems to represent big differences in the pore matrix.

Water absorption is the property with the most remarked difference between NA and RCA, and it is owed to the attached mortar on the surface of the aggregate (20). Although both types of mixes have an almost equal quantity of RCA, the EMV methodology reduces the amount of mortar in the mix by counting the one attached to the aggregate as a part of the total needed. Theoretically speaking, ACI mixes will have bigger amount of capillary pores than EMV mixes due to the amount of total mortar in the concrete.

There is also an interesting behavior in the capillary absorption capacity when comparing same proportioning methodology and different type of aggregate. Concrete mixes elaborated with aggregate type $\mathrm{B}$ present lower capillary absorption coefficients than the ones elaborated with aggregate type A. This effect may be due to a non sorptive characteristic of a part of the aggregate. Aggregate type B has 13\% of bituminous material, which may aid to the less water intake of the specimen by lessening the capillary porosity of the concrete sample. The later behavior has been observed by Quéneudec et al. (21) in an investigation were they have tested cement based composites made with rubber aggregates in proportions ranging from $0 \%$ to $40 \%$. Their results show a high correlation of the sorptivity values with the amount of rubber aggregate used in the mix, which decreases with increasing amounts of the named aggregate.
TABLE 4. Absorption coefficients of the Bolomey based mixes

\begin{tabular}{lccccc}
\hline & \multicolumn{2}{c}{$\mathbf{0 . 4 5}$ w/c } & & \multicolumn{2}{c}{$\mathbf{0 . 6}$ w/c } \\
\cline { 2 - 3 } \cline { 5 - 6 } & $\mathbf{k}$ & $\sigma$ & & $\mathbf{k}$ & $\sigma$ \\
\hline BOLCON 20\% & 0.0034 & 0.0002 & & 0.0052 & 0.0006 \\
BOLEMV 20\% & 0.0027 & 0.0003 & & 0.0046 & 0.0007 \\
BOLCON 0\% & 0.0022 & 0.0006 & & 0.0043 & 0.0010
\end{tabular}

In Table 4, for the case of the Bolomey based mixes and the $0.45 \mathrm{w} / \mathrm{c}$ ratio, BOLEMV $20 \%$ presents lower capillary absorption coefficient than the BOLCON $20 \%$ and higher than BOLCON $\%$, although statistically speaking, after an ANOVA test, the results of the later mix turned out to have no significant difference with BOLEMV 20\%, which means that the novel method improves the RAC quality. For the 0.6 w/c ratio, the results seem to have the same tendency as the $0.45 \mathrm{w} / \mathrm{c}$ ratio but after an ANOVA test, the results show no significant difference.

By taking a look at all the results, there seems to be an important influence caused by the amount of RCA used on the mix and its w/c ratio. ACI mixes with a $0.6 \mathrm{w} / \mathrm{c}$ ratio show the higher capillary coefficients, exceeding by far the other specimens, which indicates that a $100 \%$ replacement at this w/c ratio may represent an important deterioration of a given structure due to the action of this property.

\subsection{Water penetration under pressure}

This test was performed by introducing the specimens into a device in which they were submitted to a water pressure equal to $500 \mathrm{kPa}$ for a period of $72 \mathrm{hr}$, after which the specimen is cut in half in order to determine the water penetration depth. Each mix class result of the water permeability test was obtained from the average of three different specimens, elaborated from the same batch.

The results for every ACI mix, compared to their correspondent EMV ones, show higher water

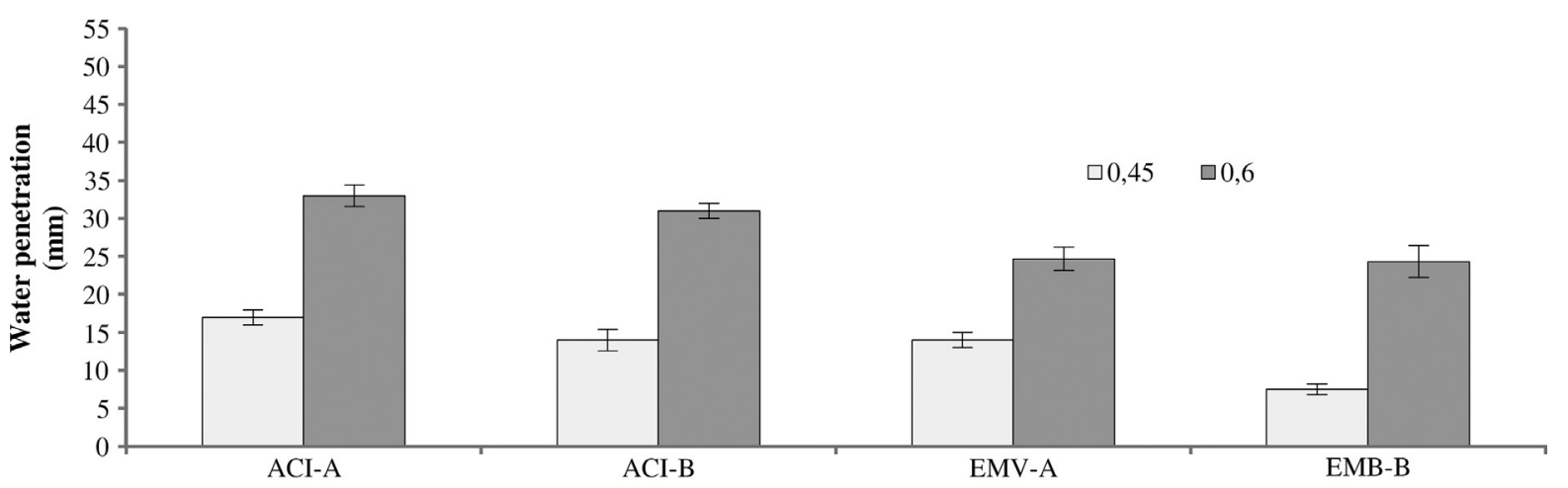

Figure 1. ACI-EMV mixes water penetration. 


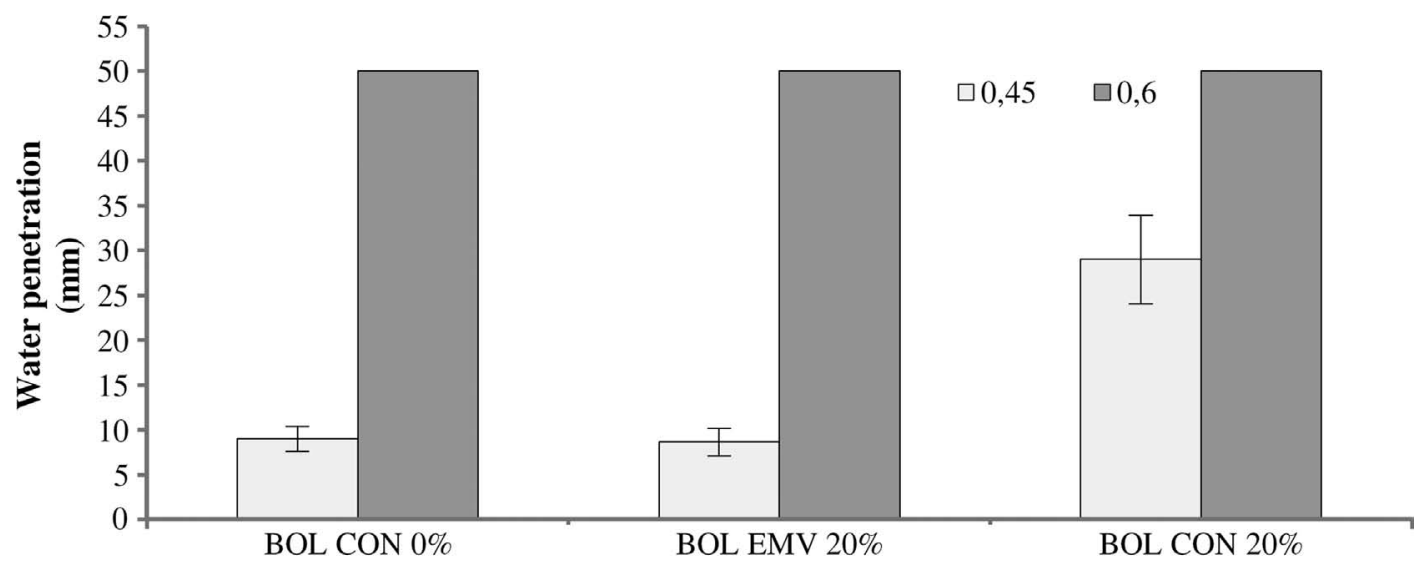

Figure 2. Bolomey mixes water penetration.

penetration, as can be seen in Figure 1. In the 0.45 w/c concrete mixes, ACI-A has an average of 1.21 times higher value than EMV-A and ACI-B is 1.87 times higher than EMV-B. For the case of the 0.6 w/c mixes, the average value of ACI-A was 1.34 times higher than its correspondent EMV-A mix and ACI-B was 1.27 times higher than the EMV-B mix. After applying an ANOVA test, significant differences were encountered between the different mixes thus then verifying that the novel method enhances the concrete characteristics over this property.

There also seems to be an improvement when comparing the specimens by type of RCA. RCA type B tends to lower the water penetration of the samples, a behavior that may be due to the nonsorptive characteristic of the bituminous aggregate that it contains, thus acting as a barrier against the water ingress.

In the case of the Bolomey mixes, for the $0.45 \mathrm{w} / \mathrm{c}$ ratio, there is a major enhancement of the concrete permeation characteristics when applying the EMV method, as it can be seen in Figure 2. Concrete mix BOLCON 20\% has 3.35 times higher average value than the BOLEMV 20\% and, the later one presents no difference with the conventional BOLCON $0 \%$. These results were verified with an ANOVA test. The case of the $0.6 \mathrm{w} / \mathrm{c}$ ratio mixes gave nonconclusive results, as all the specimens were completely penetrated by the water, but this may give us an idea of the minimums limits with respect to the w/c ratios.

An interesting point to mention is that the Bolomey based mixes in their $0.6 \mathrm{w} / \mathrm{c}$ ratio showed worst results than the ACI based mixes, even when using less or no RCA at all. This issue may be explained by the use of the AE additive, which was only used in the ACI based mixes. The AE creates a less accessible porous system within the concrete matrix (22).

In the majority of the cases, the use of the novel method improves the concrete behavior on this specific property when comparing it to the conventional RAC and, when using small replacement amounts of RCA, the novel method achieves similar values to those of a conventional concrete. These behaviors can be explained by the concrete mixes characteristics as it has been mentioned before, which are certainly closer to those of a NAC than to a conventionally designed RAC.

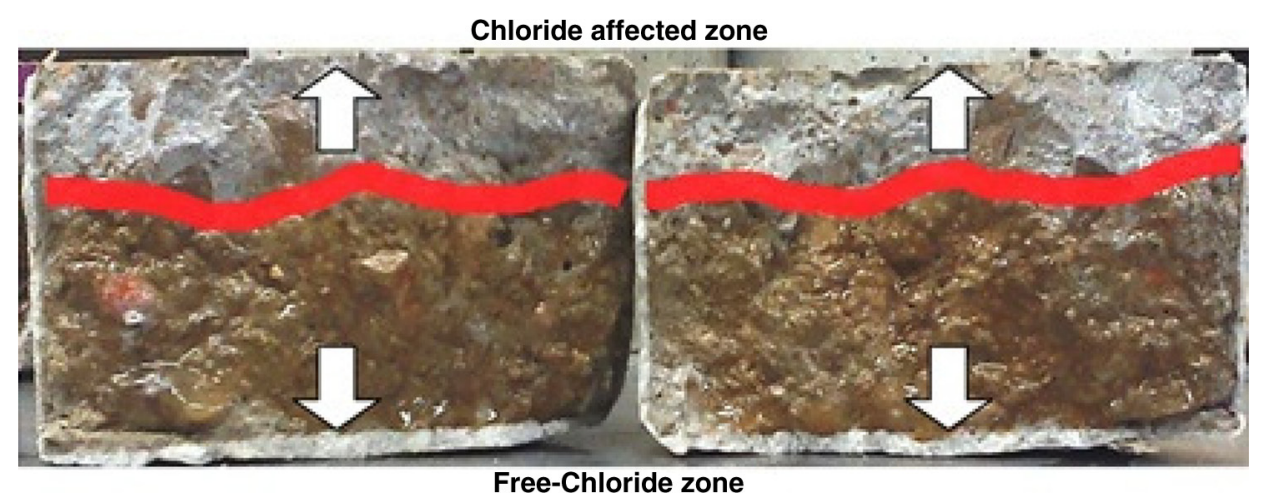

Figure 3. Chlorides affected zones demarcation. 
TABLE 5. Chlorides penetration depth obtained by $\mathrm{AgNO}_{3}$ solution spraying on ACI based mixes

\begin{tabular}{lcccc}
\hline & ACI-A & EMV-A & ACI-B & EMV-B \\
\hline \multirow{5}{*}{ 35d } & 18.1 & 21.0 & 15.6 & 13.7 \\
60d & 26.6 & 23.2 & 20.0 & 17.0 \\
90d & 27.0 & 25.5 & 24.4 & 22.1 \\
& & & 0.6 & \\
35d & 25.3 & 28.2 & 21.8 & 22.9 \\
60d & 26.0 & 33.4 & 24.0 & 26.2 \\
90d & 39.9 & 37.3 & 35.2 & 29.1 \\
\hline
\end{tabular}

\subsection{Chloride diffusion test}

The penetration of chlorides into concrete was determined by means of two tests, conducted over saw cut specimens of concrete. The test specimens were cured in a humidity-temperature controlled chamber for a period of 28 days, after which they were immersed in a water-sodium chloride solution.

The solution was prepared with $165 \mathrm{~g}$ of sodium chloride for every $1000 \mathrm{~g}$ of distilled water and the ratio between the specimens exposed area $\left(\mathrm{cm}^{2}\right)$ and the volume of the solution (dm3) was 50. The test specimens were sealed with an epoxy resin after the 28 days of curing, leaving only one plane face free from it, which corresponded to the one in direct contact with the solution, thus obtaining a one directional pathway through the specimen. After this, the specimens were immersed in the solution with their free faces pointing up. A container with a sealing lid was used for the latter purpose.

The chlorides penetration tests were done at 35, 60 and 90 days of exposure to the chlorides environment.

The first test was realized by spraying an $\mathrm{AgNO}_{3}$ solution in a concentration of $0.1 \mathrm{~mol} / \mathrm{L}$ on the fractured surface of the concrete specimens, obtained by splitting the sample by means of a compression testing machine, thus attaining a color change which delimits

TABle 6. Chlorides penetration depth by $\mathrm{AgNO}_{3}$ solution spraying on Bolomey based mixes

\begin{tabular}{lccc}
\hline & BOLCON 0\% & $\begin{array}{c}\text { BOLCON } \\
\mathbf{2 0} \%\end{array}$ & $\begin{array}{c}\text { BOLEMV } \\
\mathbf{2 0} \%\end{array}$ \\
\hline & & 0.45 & \\
35d & 19.0 & 16.5 & 16.5 \\
60d & 23.1 & 20.0 & 19.9 \\
$90 \mathrm{~d}$ & 29.0 & 25.7 & 25.3 \\
& & 0.6 & \\
$35 \mathrm{~d}$ & 26.4 & 27.0 & 26.8 \\
60d & 29.2 & 31.7 & 30.4 \\
90d & total & total & total \\
\hline
\end{tabular}

TABLE 7. Chlorides penetration parameters obtained by means of the NT 443 method on ACI mixes

\begin{tabular}{lcccccc}
\hline & \multirow{2}{*}{$\begin{array}{c}\text { Time } \\
\text { ID }\end{array}$} & \multicolumn{2}{c}{$\mathbf{0 . 4 5}$ w/c } & & \multicolumn{2}{c}{$\mathbf{0 . 6}$ w/c } \\
\cline { 7 - 8 } \cline { 6 - 7 } & (days) & $\mathbf{C s}(\%)$ & De $\left(\mathbf{m}^{2} / \mathbf{s}\right)$ & & Cs $(\%)$ & De $\left(\mathbf{m}^{2} / \mathbf{s}\right)$ \\
\hline ACI-A & 35 & 0.9 & $2.24 \mathrm{E}-11$ & & 0.65 & $6.56 \mathrm{E}-11$ \\
& 60 & 1.16 & $2.26 \mathrm{E}-11$ & & 1.12 & $5.47 \mathrm{E}-11$ \\
& 90 & 0.82 & $2.82 \mathrm{E}-11$ & & 0.96 & $3.55 \mathrm{E}-11$ \\
ACI-B & 35 & 1.04 & $2.19 \mathrm{E}-11$ & & 1.14 & $6.11 \mathrm{E}-11$ \\
& 60 & 1.04 & $1.98 \mathrm{E}-11$ & & 0.95 & $3.03 \mathrm{E}-11$ \\
& 90 & 0.78 & $1.91 \mathrm{E}-11$ & & 0.90 & $4.17 \mathrm{E}-11$ \\
EMV-A & 35 & 0.94 & $3.31 \mathrm{E}-11$ & & 0.69 & $4.13 \mathrm{E}-11$ \\
& 60 & 0.68 & $2.28 \mathrm{E}-11$ & & 0.93 & $4.39 \mathrm{E}-11$ \\
& 90 & 0.67 & $2.38 \mathrm{E}-11$ & & 1.03 & $2.33 \mathrm{E}-11$ \\
EMV-B & 35 & 0.73 & $2.60 \mathrm{E}-11$ & & 1.11 & $3.15 \mathrm{E}-11$ \\
& 60 & 0.69 & $2.43 \mathrm{E}-11$ & & 1.28 & $4.85 \mathrm{E}-11$ \\
& 90 & 0.66 & $2.24 \mathrm{E}-11$ & & 0.60 & $4.48 \mathrm{E}-11$ \\
\hline
\end{tabular}

the chloride penetration depth (16). The regions separated by the red line present a white zone that shows the chloride affected region, as a result from the silver chloride formation, and a brown zone which is the non-affected one, as it is shown in the Figure 3.

The results of this test do not mark the exact depth penetration of the chlorides, as the brow zone may content small amounts of it, but it gives a close approach (23). Table 5 shows the chlorides penetration results.

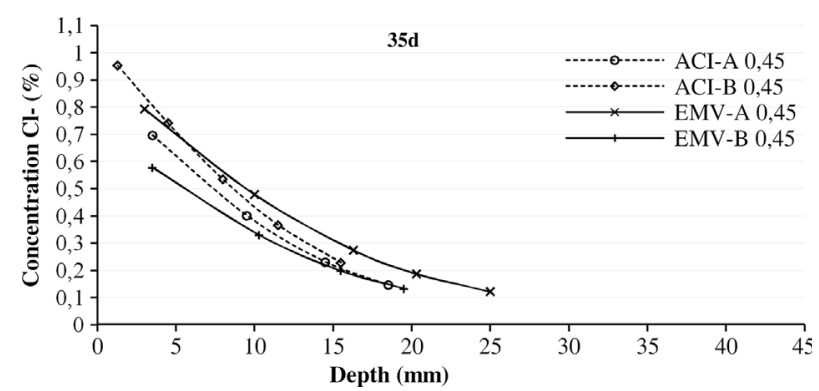

FIGURE 4. Chlorides penetration profiles at 35 day $-\mathrm{ACI}(\mathrm{w} / \mathrm{c}=0.45)$.

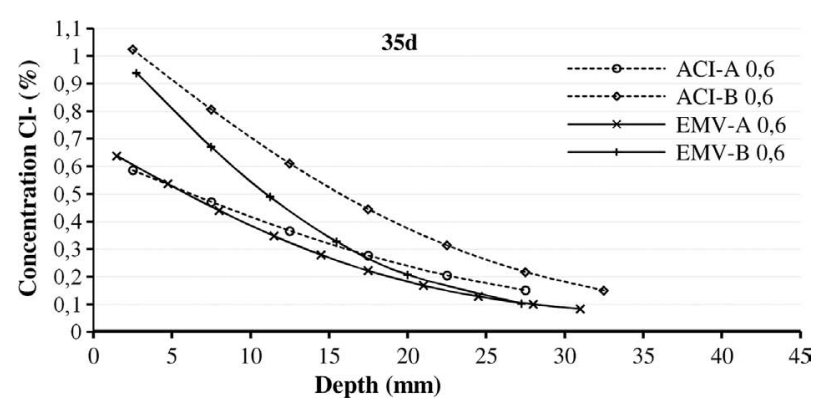

Figure 5. Chlorides penetration profiles at 35 day $-\mathrm{ACI}(\mathrm{w} / \mathrm{c}=0.6)$. 


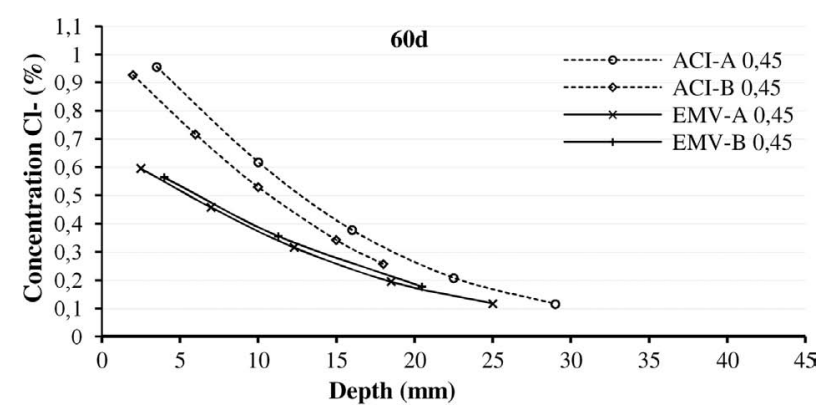

FIGURE 6. Chlorides penetration profiles at 60 days $-\mathrm{ACI}(\mathrm{w} / \mathrm{c}=0.45)$.

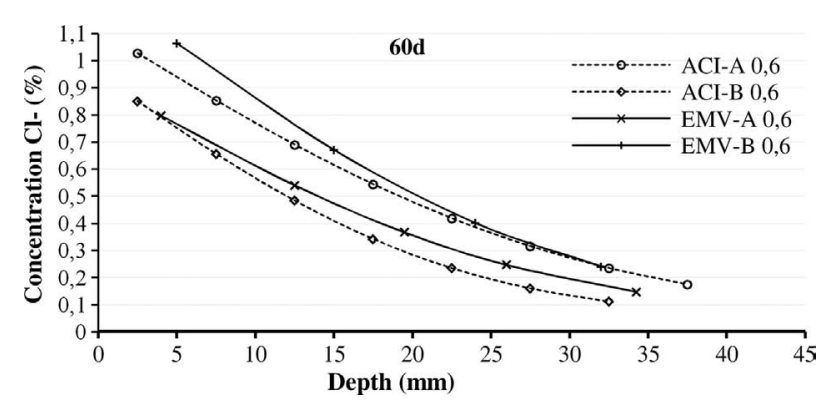

FIGURE 7. Chlorides penetration profiles at 60 days - $\mathrm{ACI}(\mathrm{w} / \mathrm{c}=0.6)$.

As it can be seen in the results for the ACI based mixes, in the case of the $0.45 \mathrm{w} / \mathrm{c}$ ratio, concrete mixes elaborated with the new proposed method show a better behavior than the conventional ones in the majority of the cases for short (35d), middle (60d) and long term (90d), being the ACI-A vs. EMV-A case, in the short term, the only exception. For the 0.6 w/c ratio mixes, the novel method shows worst behavior than the conventional method in the short and middle terms but a better behavior in the long term.

In any case, when comparing the chloride penetration in time, concrete elaborated with the new method shows lower progression rates, a behavior that may be related to the porous system of the concrete matrix, which means that the concrete will end up with a better performance along time in what chlorides penetration imply.

In the case of the Bolomey based mixes shown in Table 6 , the results for the $0.45 \mathrm{w} / \mathrm{c}$ ratio samples show a slightly better behavior in the new method than the other concrete mixes, for the short, middle and long terms of the test, although almost equal to those of the BOLCON $20 \%$. It is worth to notice that both RAC mixes have better results than the conventional mix. The latter behavior may be due to a binding effect produced by the RCA.

All $0.6 \mathrm{w} / \mathrm{c}$ ratio mixes results are similar to each other and only a slightly better behavior is seen for the BOLCON $0 \%$ mix. The results of the long term are not conclusive, due to the fact that the chloride profile was detected all along the specimens $(50 \mathrm{~mm})$ in all cases, thus not being helpful for the analysis

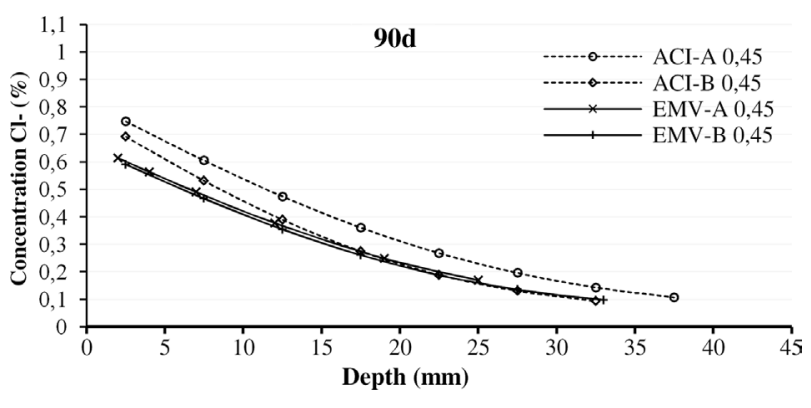

FIgURE 8. Chlorides penetration profiles at 90 days $-\mathrm{ACI}(\mathrm{w} / \mathrm{c}=0.45)$.

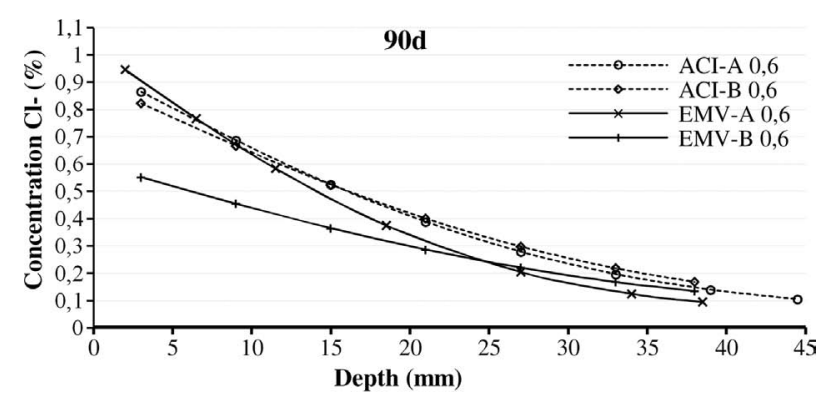

FIGURE 9. Chlorides penetration profiles at 90 days - $\mathrm{ACI}(\mathrm{w} / \mathrm{c}=0.6)$.

and being the reason why these were not taken into account when comparing the different concrete mixes. However, these results may indicate that, for a given w/c ratio, the behavior of a concrete with such characteristics against chloride penetration is negligible.

Another point that is worth to comment, is that Bolomey based mixes show worst results than the ACI based ones in the $0.6 \mathrm{w} / \mathrm{c}$ ratio. This issue is similar to what has been observed on the permeability property and, in this case, its explanation is based on the lower permeability of the samples which enhances the concretes resistance to chemical attacks (22).

The mix prepared with the new method and a $0.45 \mathrm{w} / \mathrm{c}$ ratio, show a slower progression rate in time than the rest of the concrete mixes, thus repeating

TABLE 8. Chlorides penetration parameters obtained by means of the NT 443 method on Bolomey mixes

\begin{tabular}{|c|c|c|c|c|c|}
\hline \multirow[b]{2}{*}{ ID } & \multirow{2}{*}{$\begin{array}{c}\text { Time } \\
\text { (days) }\end{array}$} & \multicolumn{2}{|c|}{0.45 w/c } & \multicolumn{2}{|c|}{$0.6 \mathrm{w} / \mathrm{c}$} \\
\hline & & Cs (\%) & $\operatorname{De}\left(\mathrm{m}^{2} / \mathrm{s}\right)$ & Cs (\%) & De $\left(\mathrm{m}^{2} / \mathrm{s}\right)$ \\
\hline \multirow[t]{3}{*}{ BOLCON 0\% } & 35 & 0.50 & $3.28 \mathrm{E}-11$ & 0.53 & $1.41 \mathrm{E}-11$ \\
\hline & 60 & 0.68 & $2.31 \mathrm{E}-11$ & 0.80 & $1.27 \mathrm{E}-11$ \\
\hline & 90 & 0.75 & $1.81 \mathrm{E}-11$ & 0.83 & $1.24 \mathrm{E}-11$ \\
\hline \multirow[t]{3}{*}{ BOLCON 20\% } & 35 & 0.72 & $3.41 \mathrm{E}-11$ & 0.59 & $1.14 \mathrm{E}-11$ \\
\hline & 60 & 1.18 & $1.54 \mathrm{E}-11$ & 0.71 & $9.61 \mathrm{E}-11$ \\
\hline & 90 & 0.95 & $1.89 \mathrm{E}-11$ & 0.83 & 4.17E-11 \\
\hline \multirow[t]{3}{*}{ BOLEMV 20\% } & 35 & 0.59 & $4.01 \mathrm{E}-11$ & 0.54 & $9.05 \mathrm{E}-11$ \\
\hline & 60 & 0.77 & $2.13 \mathrm{E}-11$ & 0.84 & $6.76 \mathrm{E}-11$ \\
\hline & 90 & 0.70 & $1.92 \mathrm{E}-11$ & 0.89 & $6.56 \mathrm{E}-11$ \\
\hline
\end{tabular}




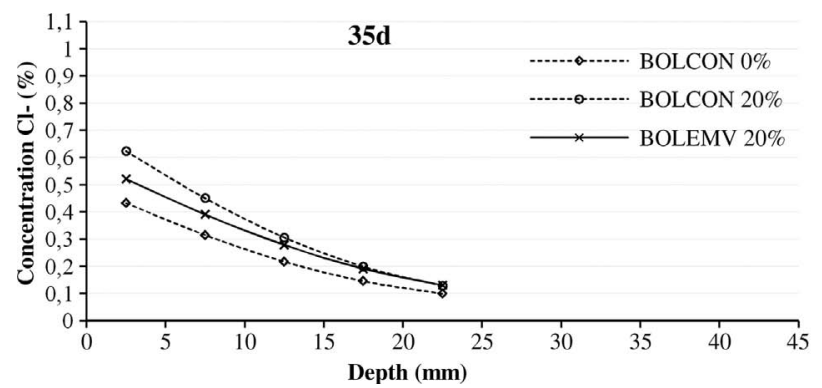

Figure 10. Chlorides penetration profiles at 35 days - Bolomey $(\mathrm{w} / \mathrm{c}=0.45)$.

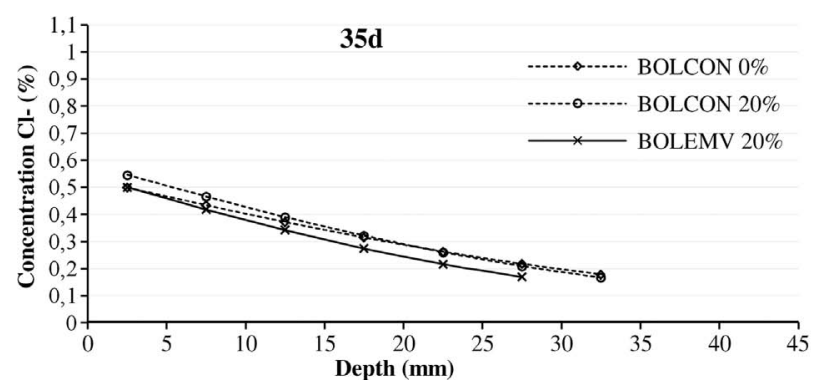

FIgURE 11. Chlorides penetration profiles at 35 days - Bolomey $(\mathrm{w} / \mathrm{c}=0.6)$.

the behavior seen in the ACI based mixes. However, this is not seen in the $0.6 \mathrm{w} / \mathrm{c}$ ratio mixes, where the BOLCON $0 \%$ has the slower progression, followed by the BOLEMV 20\% mix, but because this effect is observed taking into account only two ages (35 and 60 days), these behaviors may not be accurate.

The second test for the chlorides determination was done following the specifications of the NORDTEST method NT BUILD 443 (17) and NT BUILD 208 (24). The chloride determination consists of taking concrete powder samples from the inside part of the specimen, at different depths of it and, afterwards, measuring the chloride content of these powder samples by titration. A device consisting of a crown type bit connected to a power drill was installed in order to obtain the samples. Different methods and devices were tested before starting with the samples extraction. At the end, the commented methodology was chosen because it gave the best results, although it implies an important amount of time due to the velocity of the extraction and the different depths at which the samples need to be obtained. This, plus the large amount of specimens resulted in an extended campaign. The previous test served as a benchmark in order to set an approximate depth of samples extraction.

After this, a non-linear regression analysis by means of the least squares fit method is performed in order to obtain the chloride transport coefficient (De) and the chloride concentration at the surface (Cs). With the results of the regression analysis, the

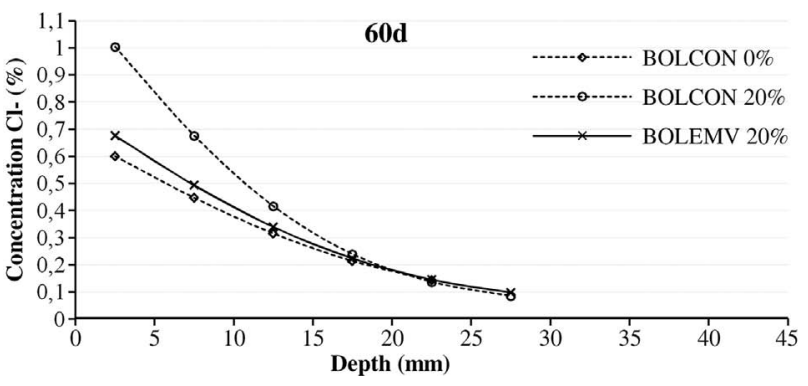

FIgure 12. Chlorides penetration profiles at 60 days - Bolomey $(\mathrm{w} / \mathrm{c}=0.45)$.

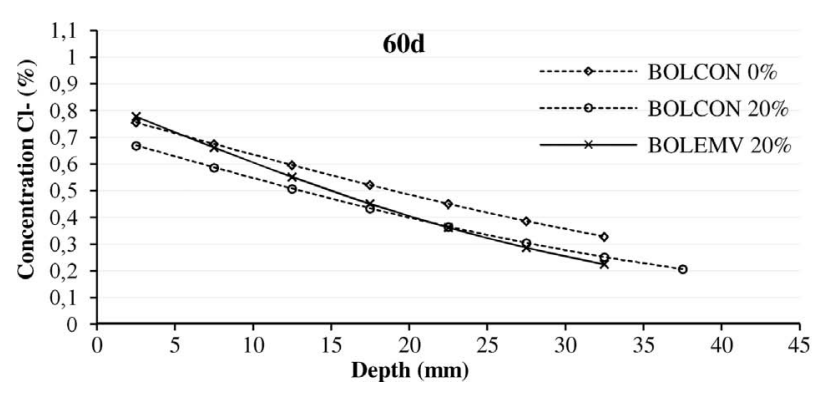

FIGURE 13. Chlorides penetration profiles at 60 days - Bolomey $(\mathrm{w} / \mathrm{c}=0.6)$.

behavior of the different concrete mixes to the chloride environment was examined.

As it can be seen in Table 7, the non-steady states of diffusion in all the cases are higher when using a $0.6 \mathrm{w} / \mathrm{c}$ ratio than the $0.45 \mathrm{w} / \mathrm{c}$ ratio. This behavior follows the trend encountered in the literature (25-28). The higher porosity of the $0.6 \mathrm{w} / \mathrm{c}$ ratio specimens allows the chlorides to go faster and in bigger amounts into the concrete matrix. Also, as time passes, the tendency of the majority of the diffusion coefficients is to decline.

In Figures 4 to 9 the chlorides penetration profiles in time are shown, for the case of ACI based mixes. Figure 4, shows similar trends for the EMV based mixes and the ACI ones, indicating a slightly higher binding capacity for the latter ones, a behavior that has been studied by Nilsson et al. (29). This higher binding capacity is attributed to the higher cement content of those mixes. Again, in Figure 6, the same behavior can be found but with greater changes in the chlorides concentrations. Indeed, ACI mixes achieve higher binding capacity as a result of the cement content but, as they have more porosity, the amount of total chlorides penetrating the sample in the first layers is also larger, decreasing in a bigger rate than the EMV mixes along their depth. In Figure 8, both types of mixes show a similar trend.

Mixes with $0.6 \mathrm{w} / \mathrm{c}$ ratio show a sort of random behavior, as the different samples binding capacity trends changes along the chosen test ages, thus presenting non-congruent results. It seems that to certain w/c ratio, the chlorides penetration behavior is 


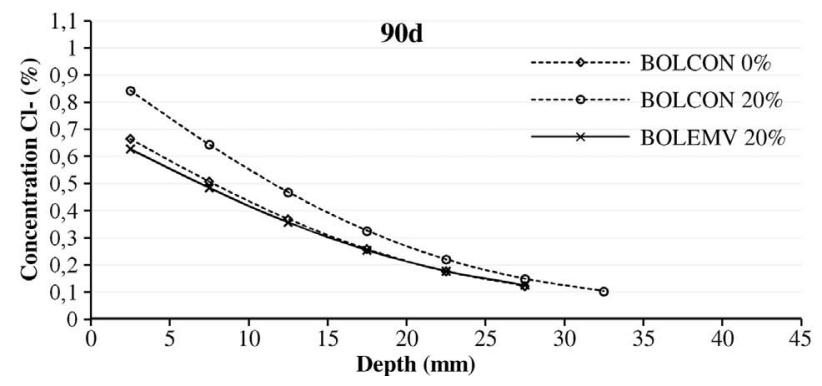

FIgURE 14. Chlorides penetration profiles at 90 days - Bolomey $(\mathrm{w} / \mathrm{c}=0.45)$.

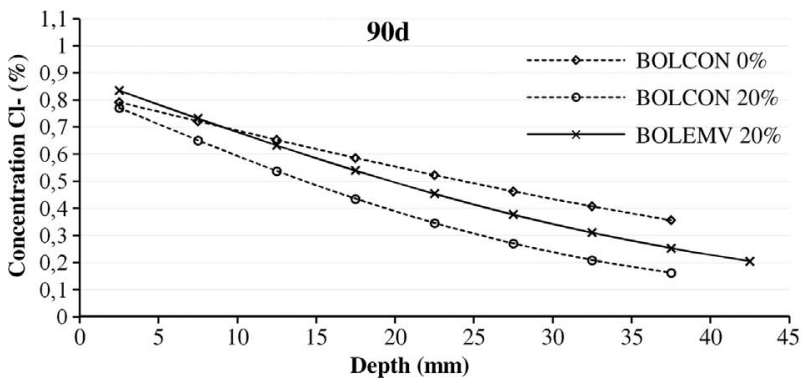

FIgURE 15. Chlorides penetration profiles at 90 days - Bolomey $(\mathrm{w} / \mathrm{c}=0.6)$.

governed by other factors; most probably, the characteristics related with the porosity of the sample take high importance.

In Table 8, it can be seen that there may be a trend indicating that at higher age of testing, the chloride concentration on surface tends to increase and the chloride transport coefficient tends to decrease. These results indicate that the deposition of chlorides on the surface is higher over time, and that there may be a connection with the amount of chlorides penetrating the sample which decreases due to a clogging effect. As times passes, chlorides are filling the concrete voids, thus obstructing the chloride penetration and so lowering the diffusion coefficient.

$0.6 \mathrm{w} / \mathrm{c}$ ratio mixes, as in the ACI based ones seen before, show the same behavior when compared to the $0.45 \mathrm{w} / \mathrm{c}$ ratio ones in terms of the diffusion coefficient, as they present higher values in all of the cases.

From Figures 10 to 15 , shown above, it can be notice that in the case of the $0.45 \mathrm{w} / \mathrm{c}$ ratio, there is a clear trend for the chlorides behavior that indicates the different binding capacity of the concrete mixes. BOLCON 20\% is the concrete achieving the higher binding capacity. This can be explained by the cement and RCA content of the mix. Both of them cause chlorides binding and, in this specific case, both achieve the maximum quantities compared to the other mix proportions. After, BOLEMV 20\% seems to be the mix binding more chlorides, a behavior that can be seen in the figures at 35 and 60 days of exposure, with the exception of the 90 days figure which indicates an almost equal behavior than that of the BOLCON $0 \%$ mix. This seems to indicate that the governing parameter for the chloride binding capacity is the $20 \%$ aggregate replacement, over the $8 \%$ cement content difference.

Again, as in the ACI based mixes, the $0.6 \mathrm{w} / \mathrm{c}$ ratio mixes do not show a clear tendency over all the obtained results, thus impeding an accurate conclusion over the chloride binding behavior. However, it can be said that for a given w/c ratio, the porous system of the concrete matrix may be the governing parameter over this property, thus leaving all of the other characteristics in second place. This assumption is of high importance, because it determines a limit for the w/c ratio of a concrete submitted to a certain chloride environment, since it may not be possible to avoid the deterioration of a given structure due to the chlorides attack.

\section{CONCLUSIONS}

ACI based mixes proportioned by the EMV method, in both 0.45 and $0.6 \mathrm{w} / \mathrm{c}$ ratios, show better behavior in the capillary absorption and water penetration properties than the RAC prepared with conventional methods.

Bolomey based mixes proportioned with the adaptation of the EMV method, in the $0.45 \mathrm{w} / \mathrm{c}$ ratio, show better behavior than the conventional RAC and similar to the NAC in the capillary absorption and water penetration properties. In the $0.6 \mathrm{w} / \mathrm{c}$ ratio, capillary absorption shows similar results for all the mixes and non-conclusive in the case of the water penetration property.

The chlorides penetration profiles show that the chloride binding behavior is better when, combined, higher are the RCA and cement contents on a mix, for the $0.45 \mathrm{w} / \mathrm{c}$ ratio cases.

As the available water for cement hydration is the same but the cement content is different, the conventional RAC may have larger binding capacity, due to the combined effect that the RCA quantity and the amount of hydration products, as CSH gel, have.

In most of the cases, ACI based mixes with RCA-B gave better results than the ones with RCA$A$, presumably because of the presence of bituminous material in its composition.

The use of a $0.6 \mathrm{w} / \mathrm{c}$ ratio is not recommended for the given conditions because, in general terms, it worsens the properties of the concrete mixes. It also makes them difficult to compare because of the lack of consistency and random behavior of their data.

The use of the EMV method and its adaptation to Bolomey achieves good results in what the studied properties concerns and, moreover, it does it with important cement content reductions. 


\section{REFERENCES}

1. Glavind, A.; Munch-Petersen, C. (2000) 'Green' concrete in Denmark. Structural Concrete, 1 [1], 1-7. http://dx.doi. org/10.1680/stco.2000.1.1.19

2. Razaqpur, A.G.; Fathifazl, G.; Isgor, B.; Abbas, A.; Fournier, B.; Foo, S. (2010) How to produce high quality concrete mixes with recycled concrete aggregate, Construction Waste Recycling and Civil Engineering Sustainable Development. Proceedings of the ICWEM 2010, 11-35.

3. ACI Committe 555: Removal and Reuse of Hardened Concrete - ACI 555R-01, ACI Committee, Detroit, (2001).

4. EPA - US Environmental Protection Agency: Inventory of U.S. Greenhouse Gas Emissions and Sinks (EPA 430-R11-005), EPA (U.S. Environmental Protection Agency), Washington, (2011).

5. Maier, P.L.; Durham, S.A. (2012) Beneficial use of recycled materials in concrete mixtures. Construc. Build. Mat. [29], 428437. http://dx.doi.org/10.1016/j.conbuildmat.2011.10.024

6. Jiménez, C.; Barra, M.; Valls, S.; Aponte, D.; Vázquez, E. (2013) Equivalent Mortar Volume (EMV) method for proportioning recycled aggregate concrete: Validation under the Spanish context and its adaptation to Bolomey methodology for concrete proportioning. Mater. Construcc. http://dx.doi.org/10.3989/mc.2012.01112.

7. Comisión Permanente del Hormigón: Instrucción de Hormigón Estructural. EHE-08, Ministerio de Fomento. Madrid (2008).

8. Barra, M.: Estudio de la durabilidad del hormigón de árido reciclado en su aplicación como hormigón armado. Barcelona (1996).

9. ASTM International: ASTM C143/C 143M - 10a Standard Test Method for Slump of Hydraulic Cement Concrete, ASTM International, West Conshohocken, (2010).

10. ASTM International: ASTM C231/C 231M - 10 Standard Test Method for Air Content of Freshly Mixed Concrete by the Pressure Method, ASTM International, West Conshohocken, (2010).

11. Comité Técnico AEN/CTN 83 Hormigón: UNE-EN 123907:2009. Ensayos de hormigón endurecido. Parte 7: Densidad del hormigón endurecido, AENOR. Madrid (2009).

12. Comité Técnico AEN/CTN 83 Hormigón: UNE-EN 12390-3: 2009/AC. Ensayos de hormigón endurecido. Parte 3: Determinación de la resistencia a compresión de probetas, AENOR. Madrid (2009).

13. Comité Técnico AEN/CTN 83 Hormigón: UNE 83316:1996. Ensayos de hormigón. Determinación del módulo de elasticidad en compresión, AENOR. Madrid (2009).

14. Comité Técnico AEN/CTN 83 Hormigón: UNE 83892: 2008. Durabilidad del hormigón. Métodos de ensayo. Determinación de la absorción de agua por capilaridad del hormigón endurecido-Método Fagerlund, AENOR. Madrid (2009).

15. Comité Técnico AEN/CTN 83 Hormigón: UNE-EN 12390-8:2001. Ensayos de hormigón endurecido. Parte 8:
Profundidad de penetración de agua bajo presión, AENOR. Madrid (2009).

16. Otsuki, N., et al. (1992) Evaluation of $\mathrm{AgNO}_{3}$ Solution Spray Method for Measurement of Chloride Penetration into Hardened Cementitious Matrix Materials. ACI Materials Journal, 89, 587-592.

17. NORDTEST: NT BUILD 443:1995. Hardened Concrete: Accelerated Chloride Penetration, NORDTEST. Espoo (1995).

18. Comité Técnico AEN/CTN 83 Hormigón: UNE 83966: 2008. Durabilidad del hormigón. Métodos de ensayo. Acondicionamiento de probetas de hormigón para los ensayos de permeabilidad a gases y capilaridad, AENOR. Madrid (2008).

19. Castro, J.; Bentz, D; Weiss, J. (2011) Effect of sample conditioning on the water absorption of concrete. Cem. Concr. Comp, 33, 805-813. http://dx.doi.org/10.1016/j. cemconcomp.2011.05.007.

20. Hansen, T.C. (1992) Recycling of Demolished Concrete and Masonry. RILEM, Londres.

21. Quéneudec, M.; Benazzouk, A.; Douzane, O. (2004) Transport of fluids in cement-rubber composites. Cem. Concr. Comp., 26, 21-29. http://dx.doi.org/10.1016/ S0958-9465(02)00119-1.

22. Grupo de trabajo 2/3. Aditivos químicos para Hormigón Estructural.: Monografía 16. Manual de Tecnología de Aditivos para Hormigón, ACHE (Asociación CientíficoTécnica del Hormigón Estructural). (2010). ISBN: 978-84-89670-70-9.

23. He, F.; Shi, C.; Yuan, Q.; Chen, C.; Zheng, K. (2012) AgNO -based colorimetric methods for measurement of chloride penetration in concrete. Construc. Build. Mat. 26, 1-8. http://dx.doi.org/10.1016/j.conbuildmat.2011.06.003

24. NORDTEST: NT BUILD 208. Concrete, Hardened: Chloride Content, NORDTEST. Espoo (2005).

25. Frederiksen, J.M.; Sorensen, H.E.; Andersen, A.; Klinghoffer, O. (1997) HETEK, The effect of the w/c ratio on chloride transport into concrete - Immersion, migration and resistivity tests, Road Directorate - Ministry of Transport. Denmark, ISSN/ISBN: 0909-4288 / 8774927358.

26. Cement Concrete \& Aggregates Australia: Chloride Resistance of Concrete, Cem. Concr. Aggreg. Australia. Australia, (2009).

27. Ollivier, J.P. (1998) Durability of Concrete, Escola Politécnica da USP/Departamento de Engenharia de Construcao Civil. Sao Paulo, ISSN: 0103-9830.

28. Han, SH. (2007) Influence of diffusion coefficient on chloride ion penetration of concrete structure. Construc. Build. Mat, 21 [2], 370-378. http://dx.doi.org/10.1016/j. conbuildmat.2005.08.011.

29. Nilsson, L.-O.; Poulsen, E.; Sandberg, P.; Sorensen, H.E.; Klinghoffer, O. (1996) HETEK, Chloride penetration into concrete, State-of-the-Art, Transport processes, corrosion initiation, test methods and prediction models, Danish Road Directorate. Denmark, ISSN/ISBN: 0909-4288 / 87 74917366. 